\title{
LINKS BETWEEN FINANCIAL STATEMENTS AND MANAGEMENT COMMENTARY
}

The author's aim is to identify the links between two reporting systems: financial and nonfinancial. In this article, the connection between the financial statements and the management report will be shown. The work concerns the management report after the introduction of the obligation of non-financial reporting in the form of additional information in this report, or by means of a separate statement on non-financial information.

The objective was achieved by means of literature studies in the field of accounting, as well as the analysis of legal acts, based on which the relations between the two reports should be determined. Deductive and inductive reasoning and the method of critical, comparative and descriptive analysis and synthesis were used to formulate conclusions. The existence of links between the management report and the financial statement has been demonstrated. These links may pose a risk of repetition and non-compliance. It is desirable that these links should be made clear to people responsible for drawing up both reports. Particular attention should be paid to the presentation of this information and steps should be taken in the accounting internal control procedures and internal audit, perhaps to confirm that the relevant information has been reconciled and to avoid unnecessary repetition.

The results of the research show that there are so many connections, including non-financial information, that it is worthwhile to provide them and their verification as a conscious and organized activity. This will build the image of the company in the eyes of the report readers.

Key words: financial statements, management report, quality of information JEL Code: M14,

\section{Introduction}

There is an approach to business reporting which asserts that 'A fundamental element of the information policy of a company operating in a global environment is its reporting -

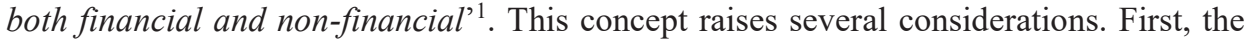
idea that reporting is a "fundamental element" would mean that there are other elements which are not considered "fundamental." Second, the idea that non-financial reporting should also be combined with financial reporting as part of a company's information policy. Perhaps this is only the case for companies operating in a global environment, and is not applicable to companies operating locally.

Corporate reporting can be divided into financial and non-financial information, but this is only one area of corporate reporting; there are many others, including non-

${ }^{1}$ E. Walińska, J. Gad: The key corporate reporting tools in the practice of the Polish capital market - case study, 'Theoretical Journal of Accounting', Accountants Association in Poland, 92 (148), 2017, pp. 207-226, p. 207. 
financial information, corporate social responsibility, sustainable and integrated reports. Contemporary accounting statements have become very comprehensive and multilayered, with broad meaning hidden in every sentence. At the same time, such reporting is expected to provide specific, clear and transparent information. This goal is certainly not supported by duplicating information, presenting the same facts in different variations and leading to different interpretations and justifications. Therefore, each time new disclosures are introduced, they should be linked to other information which has already been publicly disclosed, especially when presented as related documents. The context of these links would then need to be checked to see if previously disclosed information is being duplicated, corrected, explained, supplemented, or reinterpreted. It seems necessary to continue to identify and raise awareness of the links between the two reports, and in particular - and the goal of this article - between the financial statements and the management report. It is necessary because it is impossible to predict with certainty the reception of information by the reader, the way this reception will evolve, and how the understanding of information may change. The importance for reporters of understanding these relationships cannot be overlooked, either. Moreover, in the perspective of non-financial reporting, such analysis is a starting point for making the subsequent links with later documents more known. This identification will allow to add more links in the next step and find a systemic organizational approach to preparing related information.

The study, the conclusions of which are included in this article, concerns the indication of connections between the financial statements described in Appendix 1 to the Accounting $\mathrm{Act}^{2}$ and the management commentary, also within the meaning of the Accounting Act after the introduction of the obligation to report non-financial information. In a situation where the scope of information in the financial statements is very diverse and has recently undergone numerous changes, it is necessary to clarify this subject. The research is intended to address the assumptions of disclosure and therefore the intentions regarding the information value required for disclosure rather than the practice of disclosure. Therefore, study of the accounting literature and analysis of legal acts was conducted. This allowed the necessary disclosures and the connections between the information contained in the two reports in question to be made. The article has the following structure: gist of the management commentary, main content of the management commentary, links between the values in the financial statements and the management commentary, and conclusions. The identification of the desired links can also be used to define the requirements for the revision and control of the information so that they lead to such links and thus help to improve the quality of the information.

\section{Gist of the management commentary}

'For many years the management commentary has not been the subject of interest of Polish authors of works on reporting or financial accounting. ${ }^{3}$. This is surprising, considering the notion of 'the entity's management commentary as the primary source of

\footnotetext{
2 Accounting Act of 29 September 1994, Dz.U. z 2021 r. pos. 217 as amended.

${ }^{3}$ B. Bek-Gaik, J. Krasodomska: Non-financial disclosures as contemporary corporate reporting - definition, sources and proposed research directions, Cracow Review of Economics and Management, 2018; 2 (974): 25-40, https://doi.org/10.15678/ZNUEK.2018.0974.0202, p. 30.
} 
non-financial information' 4 and in view of the fact that integrated reporting is now being identified as a tool for communication between a company and its stakeholders ${ }^{5}$ and is receiving a lot of attention. The question arises as to why the management commentary has not received such attention. After all, it remains the main source of non-financial information, at least in the sense that it concerns a much larger number of entities than integrated reporting. It allows many units to inform about something more than just financial data. Despite changes in the area of disclosure by companies, 'The key element of corporate reporting is the financial statement, which for many years was the only corporate report, but today is one of many' ${ }^{6}$.

There are views that the management commentary is the link between the financial statements and other reports and that 'it has become a basic non-financial report accompanying the financial statements ${ }^{\text {'7 }}$. It must be said that there are no other reports accompanying it in the way that the management commentary does. While the creation of reports for many entities is a challenge in terms of their very construction, in the case of a management commentary, the Accounting Act specifies precisely what position it takes in relation to the financial statements and who is responsible for their content. It also defines its scope ${ }^{8}$. However, non-financial information is also included in the management commentary because generally it can be found in 'the following corporate documents: the annual report, namely its management commentary, the social report and the integrated report ${ }^{9}$.

In describing the essence of the management commentary, attention may be drawn to its goals and addressees, its scope, its preparers and the way it is made public. To achieve the aim of this article it is necessary to mention the first two. The management commentary and the financial statements have a slightly different purpose that involves defining the goals and addressee. A management commentary is not prepared by all entities that prepare financial statements. Both are, however, intended to communicate the information mainly needed by capital providers, and it is to them that the management commentary is specifically addressed. It is to be used by them to assess an entity, or more precisely its purpose - in accordance with National Accounting Standard No. 9 'Management commentary'10: 'to improve the knowledge of the entity by providing its users with relevant information in complementation to the financial

\footnotetext{
${ }^{4}$ W. Skoczylas, W. Dziadul: Diagnosis of the scope of non-financial information. Disclosure by polish companies, Studies and Work of the Collegium of Management and Finance, Warsaw School of Economics, 164/2018, pp. 117-135, p. 119.

${ }^{5}$ A. Krzysztofek: Integrated reporting on the example of Respect Index enterprises, Journal of Management and Finance Vol. 16, No. 2/2018

${ }^{6}$ E. Walińska, J. Gad: The key corporate reporting tools in the practice of the Polish capital market - case study, 'Theoretical Journal of Accounting', Accountants Association in Poland, 92 (148), 2017, pp. 207-226, p. 207.

${ }^{7}$ E. Walińska, J. Gad: The key corporate reporting tools in the practice of the Polish capital market - case study, 'Theoretical Journal of Accounting', Accountants Association in Poland, 92 (148), 2017, pp. 207-226, p. 209 .

${ }^{8}$ Accounting Act of 29 September 1994, Dz.U z 2021 r. pos. 217 as amended, art. 49.

${ }^{9}$ B. Bek-Gaik, J. Krasodomska: Non-financial disclosures as contemporary corporate reporting - definition, sources and proposed research directions, Cracow Review of Economics and Management, 2018; 2 (974): $25-$ -40, https://doi.org/10.15678/ZNUEK.2018.0974.0202, p. 28.

${ }^{10}$ Announcement of the Resolution of the Accounting Standards Committee on the adoption of an update of National Accounting Standard No. 9 Management commentary, Dz. Urz. MRiF 2018.4.
} 
statements (...) and additional information to facilitate the assessment of the entity - its activities, situation, intentions and prospects for development ${ }^{11}$. As a rule, the information is intended to be complementary or additional and, most importantly, to enrich knowledge. Consequently, reading only the financial statements does not support the reader with that information.

In addition, according to the standard, there is this statement 'contains a balanced and objective presentation and analysis of information about the entity, corresponding to its specificity, size and complexity ${ }^{\prime 2}$. According to the standard, it contributes to a better understanding of the entity and reduces risks (the standard does not specify which). Thus, the providers of capital can read both documents and complete the information from one to another. If they are dealing with the same issues, they will probably look for confirmation of information in each one, as well as for confirmation of the conclusions they have drawn. This is because both documents ultimately relate to the description of the same entity (unit) and subject (resources and activities) during the reporting period and the creation of a single assessment by a single reader. The question arises as to what informational links readers should be able to find, provided they have enough knowledge and skills.

\section{Main contents of the management commentary}

The scope of the management commentary is determined by the Accounting Act $^{13}$, and is specified in National Accounting Standard No. 9 'Management commentary'14. The law, when it was created in 1994 , required that it should include ${ }^{15}$ :

"significant information about the property and financial situation, including the assessment of the effects achieved and the indication of risk factors and description of threats, and in particular information about:

1) events that significantly influence the entity's activity, which occurred in the financial year, as well as after its completion, until the date of approval of the financial statement,

2) anticipated development of the entity,

3) major achievements in the field of research and development,

4) current and anticipated financial situation.

Currently, it additionally expects information on ${ }^{16}$ :

1) own shares, including:

a) the reason for the acquisition of own shares during the financial year,

\footnotetext{
${ }^{11}$ Announcement of the Resolution of the Accounting Standards Committee on the adoption of an update of National Accounting Standard No. 9 Management commentary, Dz. Urz. MRiF 2018.4, point 4.1

12 Announcement of the Resolution of the Accounting Standards Committee on the adoption of an update of National Accounting Standard No. 9 Management commentary, Dz. Urz. MRiF 2018.4, point 4.2

${ }_{13}$ Accounting Act of 29 September 1994, Dz.U. z 2021 r. pos. 217 as amended, art. 49.

${ }^{14}$ Announcement of the Resolution of the Accounting Standards Committee on the adoption of an update of

National Accounting Standard No. 9 Management commentary, Dz. Urz. MRiF 2018.4.

${ }^{15}$ Accounting Act of 29 September 1994, Dz.U. z 2021 r. pos. 217 as amended, art. 49 ust. 2.

${ }^{16}$ Accounting Act of 29 September 1994, Dz.U. z 2021 r. pos. 217 as amended, art. 49 ust. 2.
} 
b) the number and nominal value of shares acquired and disposed of during the financial year, or in the absence of nominal value, their book value, as well as the part of the share capital they represent,

c) in the case of acquisition or disposal for a consideration, the equivalent of those shares,

d) the number and nominal value of all shares acquired and retained, or in the absence of nominal value, their book value, as well as the part of the share capital they represent,

2) branches (plants) owned by the entity,

3) financial instruments in respect to:

a) risks: changes in prices, credit, significant disruptions of cash flows and loss of financial liquidity to which the entity is exposed,

b) financial risk management objectives and methods adopted by the entity, including hedging methods.

In addition, where relevant for the assessment of an individual's development, performance and situation, it should also include at least ${ }^{17}$ :

1) key financial performance indicators related to the entity's operations;

2) key non-financial performance indicators related to the entity's operations and information on employee and environmental issues.

However, if there is a link between the values reported in the management commentary and the information in the entity's annual financial statements, it is the entity's management commentary that should include references to and additional explanations for the amounts reported in the financial statements ${ }^{18}$.

The amount of information required by the Act has increased significantly, mainly in recent years, especially in the area of non-financial information, which occupies a relatively large part of the report. However, only the relationship between the values shown in the annual financial statements and the information in the entity's management commentary is of interest here, which should be indicated and explained.

The standard itself raises such issues as:

- purpose, nature and quality characteristics of the management commentary

- rules of preparation and presentation of the management commentary

- content of the management commentary

- characteristics of activities and resources

- objectives and risks

- results of operations and financial situation

- prospects

- statement on application of corporate governance

- $\quad$ statement (report) on non-financial information.

Despite its legal status, volume and detail, the Standard 'contains only a set of desirable features, content and layout of the management commentary, as well as guidelines for its preparation and presentation ${ }^{19}$.

${ }^{17}$ Accounting Act of 29 September 1994, Dz.U. z 2021 r. pos. 217 as amended, art. 49 ust. 3.

${ }^{18}$ Accounting Act of 29 September 1994, Dz.U. z 2021 r. pos. 217 as amended, art. 49 ust. 3a.

- $\quad{ }^{19}$ W. Skoczylas, W. Dziadul: Diagnosis of the scope of non-financial information. Disclosure by polish companies, Studies and Work of the Collegium of Management and Finance, Warsaw School of Economics, 164/2018, pp. 117-135, p. 122. 


\section{Links between the values in the financial statements and the management commentary}

It can be stated with certainty that the information that the Standard requires to be described in a management commentary is to some extent already present in the financial statements or even has a source or effect there. The introduction to the management commentary already indicates the name, legal form and registered office of the entity, which is understandable because it identifies the preparer, but its share of capital also appears in the same place, which is an obvious repetition ${ }^{20}$. The content of the principal part of the management commentary is described in paragraph VI of the Standard, which addresses the characteristics of operations and resources, objectives and risks, results of operations and financial position and prospects. The following content appears in this paragraph:

Concerning characteristics of activities and resources:

- description of the key areas of its activity and its effects (point 6. 4) ;

- information related to this in the financial statements, the volume and structure of sales revenue;

- key macroeconomic factors such as: GDP growth rate, interest rates, inflation rate, exchange rates, etc., (point 6. 12)

- these factors may be used to determine values in the financial statements and may be disclosed in the notes to the financial statements e. g. the exchange rates adopted for the valuation of financial statement items denominated in foreign currencies ${ }^{21}$;

- indication of the main items of the assortment (point 6.14)

- the notes to the financial statements show the material structure of net revenues from sales of goods and products, to the extent that these types and markets differ significantly from each other considering the principles of organizing sales of products and providing valuation services ${ }^{22}$;

- major achievements and scope of research and development work (point 6. 18)

- in the notes to the financial statements the amount of costs of completed development work and information on costs related to research and development work which have not been classified as intangible assets is $\operatorname{disclosed~}^{23}$

- information on remuneration (point 6.21)

- in the case of entities which prepare the profit and loss account in the calculation variant in the notes to the financial statements, information on remuneration and, in all cases in the notes to the financial statements, information on remuneration, including profit-based remuneration, paid or due to persons forming part of the bodies of the company and any liabilities arising from pensions and benefits of a similar nature for former members of those

\footnotetext{
${ }^{20}$ Announcement of the Resolution of the Accounting Standards Committee on the adoption of an update of National Accounting Standard No. 9 Management commentary, Dz. Urz. MRiF 2018.4. point 6.1.

${ }^{21}$ Accounting Act of 29 September 1994, Dz.U. z 2021 r. pos. 217 as amended, annex 1, point 2.3

${ }^{22}$ Accounting Act of 29 September 1994, Dz.U. z 2021 r. pos. 217 as amended, annex 1, point 2.1.

${ }^{23}$ Accounting Act of 29 September 1994, Dz.U. z 2021 r. pos. 217 as amended, annex 1, point 1.3, 2.11.
} 
bodies or liabilities incurred in connection with those pensions, indicating the total amount for each category of body ${ }^{24}$;

- number and nominal value of own shares acquired and disposed of during the financial year (item 6. 22)

- the financial statements show information about the book value of shares held item D in assets ${ }^{25}$;

Concerning results of operations and financial situation:

- the most important information about the financial situation in the form of indicators describing profitability, liquidity, assets and financial situation (point 6. 30)

- these indicators use in their formulas the items present in the financial statements;

- $\quad$ presentation of results of operations in areas of development (point 6.31)

- these results are shown in the financial statements together, so they must be reconciled;

- information on unusual, one-off events (point 6.33)

- the notes to the financial statements show the amount and nature of items of income or costs of extraordinary value or which occurred incidentally ${ }^{26}$.

No similar links were observed in the part of the management commentary: Objectives and Risks and outlook.

In point $\mathrm{V}$ of the Standard, concerning the principles of preparing and presenting the management commentary:

- $\quad$ in 5. 8. The standard requires information to be presented in a comprehensive, transparent and consistent manner, including compliance with its financial statement. This may give rise to repetition, so to ensure brevity and reduce repetition, the management commentary 'may contain internal references or markings, ensuring links with other information';

- 5. 18 describing the consistency of information indicates that it requires both internal consistency and consistency with the information in the financial statements. Then it cannot be a simple repetition of information. This is unnecessary and would probably be assessed negatively by the readers. Hence, the standard somehow indicates what it is supposed to serve and what kind of information connection it expects. It states that it is done 'in order to present the issues from the point of view of the head of unit', presents 'financial data in a different layout from the financial statements'27. This different presentation requires the data to be consolidated or restated, and therefore the reader will want to understand or check how the data has been restated by moving from individual items in the management commentary to those shown in the financial statements. All these records indicate the existence of links and, what is more important, the risk of repetition as a result of those links or incompatibilities

\footnotetext{
${ }^{24}$ Accounting Act of 29 September 1994, Dz.U. z 2021 r. pos. 217 as amended, annex 1, point 2.2, 5.4.

${ }^{25}$ Accounting Act of 29 September 1994, Dz.U. z 2021 r. pos. 217 as amended, annex 1, assets D.

${ }^{26}$ Accounting Act of 29 September 1994, Dz.U. z 2021 r. pos. 217 as amended, annex 1, point 2.2.10.

${ }^{27}$ Announcement of the Resolution of the Accounting Standards Committee on the adoption of an update of National Accounting Standard No. 9 Report on operations, Dz. Urz. MRiF 2018.4. point 5.18.
} 
caused by a lack of reconciliation. The analysis of the management commentary carried out by the Ministry of Finance in Poland indicated that28:

- $\quad$ in 29 of the cases audited, the entity has provided references to the amounts shown in the financial statements;

- $\quad$ in 87 of the cases audited, the entity has not provided such references.

It is difficult to say what such absence might mean.

\section{Conclusions}

The existence of links between the management commentary and the financial statements has been demonstrated. These links may create a risk of repetition or inconsistency of information, both in terms of financial and non-financial information, and the latter seems more difficult to explain to the readers. Therefore, steps should be taken within the reporting entity to ensure that these links:

- $\quad$ are made known to the people drawing up both reports;

- $\quad$ lead to attention being paid to the presentation of this related information;

- provide a rationale for the possible introduction of measures into internal control procedures in the accounting system to confirm that the relevant information has been reconciled and to avoid unnecessary repetition or differences;

- $\quad$ are within the internal audit function to introduce this issue into the audit tasks, including those of an advisory nature, undertaken on the auditor's initiative if the risk is not so great as to devote it to the task of providing assurance.

These actions may respond to risks arising from the links between the management commentary and the financial statements.

Given that the user of financial statements will expect the content and quality of the information in both reports to be consistent, they need to be prepared to show, first and foremost, that the entity is aware of and identifies these relationships, not to create ambiguity in the meaning of the information and, in the worst case not to be misleading. This action goes beyond the framework of the preparation of each report, although it formally belongs to the management commentary (and not to the financial statements), where the amounts shown in the financial statements, as well as the additional explanations concerning those amounts, should be referred to. As a rule, the management commentary is also prepared later, or at most in parallel with the financial statements, which may be subject to an additional audit. However, the method of its preparation is consistent with maintaining the quality of information presented in both reports. The entity will also be accounted for by the users of the reports for this consistency.

In view of the above, and stressing the links also with non-financial data, it is necessary to identify those responsible within the entity for verifying compliance with these principles. This issue of the quality of information, particularly of non-financial information, is becoming increasingly important as it is assumed that 'With the systematic development of non-financial reporting, there is a growing need to make it

28 Reporting extended non-financial information for 2017 in accordance with the Accounting Act - First experiences and good practices, Ministry of Finance, Warsaw 2019, s. 59. 
more credible', and the question is: what does verification of non-financial data mean? ${ }^{29}$. Statutory auditors undertake certain verification activities also in relation to the management commentary ${ }^{30}$ but 'verification of non-financial data is largely voluntary' $^{31}$. Therefore, the user can rely primarily on the reliability of the entity. Further investigations should lead to find a systemic organizational approach to preparing related information and define the requirements for the revision and control of the information, which will help to improve the quality of the information.

\section{Bibliography}

Accounting Act of 29 September 1994, Dz.U. z 2021 r. pos. 217 as amended Announcement of the Resolution of the Accounting Standards Committee on the adoption of an update of National Accounting Standard No. 9 Report on operations, Dz. Urz. MRiF 2018.4.

Bek-Gaik B., Krasodomska J.: Non-financial disclosures as contemporary corporate reporting definition, sources and proposed research directions, Cracow Review of Economics and Management, 2018; 2 (974): 25-40, https://doi.org/10.15678/ZNUEK.2018.0974.0202.

Krzysztofek A.: Integrated reporting on the example of Respect Index enterprises, Journal of Management and Finance Vol. 16, No. 2/2018.

Kutera M., Zyznarska-Dworczak B.: Narration in Reporting - How to Verify It?, Studies and Work of the Collegium of Management and Finance, Warsaw School of Economics, 160/2018.

Reporting extended non-financial information for 2017 in accordance with the Accounting Act First experiences and good practices, Ministry of Finance, Warsaw 2019.

Skoczylas W., Dziadul W.: Diagnosis of the scope of non-financial information. Disclosure by polish companies, Studies and Work of the Collegium of Management and Finance, Warsaw School of Economics, 164/2018.

Walińska E., Gad J.: The key corporate reporting tools in the practice of the Polish capital market - case study, 'Theoretical Journal of Accounting', Accountants Association in Poland, 92 $(148) / 2017$.

Zyznarska-Dworczak B.: The development of non-financial reporting and the possibility of its verification, Studia Ekonomiczne. Zeszyty Naukowe Uniwersytetu Ekonomicznego w Katowicach, Nr 285/2016.

\section{Powiązania między sprawozdaniem finansowym a sprawozdaniem z dzialalności}

\section{Streszczenie}

Celem autora jest identyfikacja powiązań między dwoma sprawozdawczościami: finansową i niefinansową, a w tym konkretnym artykule - między sprawozdaniem finansowym a sprawozdaniem $\mathrm{z}$ działalności, które zawiera informacje niefinansowe, ale powiązane z finansowymi. Do realizacji celu posłużyły studia literaturowe z zakresu rachunkowości, a także analiza aktów prawnych, na bazie których określono jakie powinny być relacje między tymi dwoma sprawozdaniami. Do sformułowania wniosków wykorzystano wnioskowanie dedukcyjne

\footnotetext{
${ }^{29}$ M. Kutera B. Zyznarska-Dworczak: Narration in Reporting - How to Verify It?, Studies and Work of the Collegium of Management and Finance, Warsaw School of Economics 160/2018 pp. 99-111, p. 100.

${ }^{30}$ M. Kutera B. Zyznarska-Dworczak: Narration in Reporting - How to Verify It?, Studies and Work of the Collegium of Management and Finance, Warsaw School of Economics 160/2018 pp. 99-111, p. 105.

${ }^{31}$ B. Zyznarska-Dworczak: The development of non-financial reporting and the possibility of its verification, Studia Ekonomiczne. Zeszyty Naukowe Uniwersytetu Ekonomicznego w Katowicach, Nr 285 · 2016, s. 222.
} 
i indukcyjne oraz metodę analizy krytycznej, porównawczej i opisowej oraz syntezy. Zostało wykazane istnienie powiązań między sprawozdaniem z działalności a sprawozdaniem finansowym z działalności. Powiązania te mogą rodzić ryzyko powtórzeń i niezgodności informacji. Zostało wskazane, aby powiązania te były uświadomione osobom sporządzającym oba sprawozdania, by zachowano szczególną uwagę przy prezentowaniu tych informacji i aby wprowadzono do procedur kontroli wewnętrznej w rachunkowości, i ewentualnie audytu wewnętrznego, czynności pozwalające na potwierdzenie uzgodnienia odpowiednich informacji i uniknięcia ryzyka powtórzeń i niezgodności. Wyniki badań pokazują, że powiązań jest na tyle dużo, w tym z informacjami niefinansowymi, że warto, aby zapewnienie ich i ich weryfikacji było świadomą i zorganizowaną czynnością. Będzie to budować obraz jednostki w oczach czytelnika sprawozdań.

Słowa kluczowe: sprawozdanie finansowe, sprawozdanie z działalności, jakość informacji JEL Code: M14

Information about thr outhor

Małgorzata Garstka - Doctor of Economics

Jan Kochanowski University in Kielce

Wydział Prawa i Nauk Społecznych

Katedra Ekonomii i Finansów

ul. Uniwersytecka 15, 25-406 Kielce

e-mail: malgorzata.garstka@ujk.edu.pl

ORCID: 0000-0002-0971-0274 